\title{
PENGARUH PENGETAHUAN PRODUK, KETERLIBATAN PRODUK, DAN E-WOM TERHADAP NIAT PEMBELIAN PRODUK MAX FACTOR PADA MAHASISWI FAKULTAS EKONOMI DAN BISNIS UNIVERSITAS TARUMANAGARA MELALUI WEBSITE SOCIOLLA DI JAKARTA
}

\author{
Tania Ulrica dan Yenny Lego \\ Program Studi Manajemen Fakultas Ekonomi Universitas Tarumanagara, Jakarta \\ Tania.115170214@stu.untar.ac.id
}

\begin{abstract}
The purpose of this study is to examine the effect of product knowledge, product involvement, E-WOM on purchase intention of Max Factor products in students of the Faculty of Economics \& Business, Tarumanagara University through the Sociolla website in Jakarta. The sampling method in this study was purposive sampling. The sample in this study are 100 respondents who were students of the Faculty of Economics and Business, Tarumanagara University who knew and had never bought Max Factor products on the Sociolla website in Jakarta. Data is being processed using the sofware SmartPLS 3. The results of this study are The results of this study shows that product knowledge has a significant positive effect on purchase intention, product involvement has a significant positive effect on purchase intentions, E-WOM has a significant positive effect on purchase intentions.
\end{abstract}

Keywords: Product Knowledge, Product Involvement, E-WOM, Purchase Intention.

Abstrak: Tujuan dari penelitian ini adalah untuk menguji pengaruh pengaruh pengetahuan produk, keterlibatan produk, E-WOM terhadap niat pembelian produk Max Factor pada mahasiswi Fakultas Ekonomi \& Bisnis Universitas Tarumanagara Melalui Website Sociolla di Jakarta. Metode pengambilan sampel pada penelitian ini adalah purposive sampling. Sampel dalam penelitian ini berjumlah 100 responden yang merupakan mahasiswi Fakultas Ekonomi dan Bisnis Universitas Tarumanagara yang mengetahui dan belum pernah membeli produk Max Factor pada Website Sociolla di Jakarta. Data diolah dengan menggunakan software SmartPLS 3. Hasil penelitian ini menunjukkan bahwa pengetahuan produk memiliki pengaruh positif signifikan terhadap niat pembelian, keterlibatan produk memiliki pengaruh positif signifikan terhadap niat pembelian, E-WOM memiliki pengaruh positif signifikan terhadap niat pembelian.

Kata Kunci: Pengetahuan Produk, Keterlibatan Produk, E-WOM, Niat Pembelian.

\section{LATAR BELAKANG}

Pasar Industri kecantikan Indonesia menjadi salah satu industri andalan yang berperan besar sebagai penggerak utama perekonomian di masa yang akan datang. Sebagai negara dengan populasi terbesar keempat di dunia dengan jumlah penduduk sekitar 268 juta jiwa. Hal ini menjadikan Indonesia sebagai negara yang mempunyai peluang besar untuk membangun sektor industri kecantikan. Banyaknya populasi wanita produktif di Indonesia mengakibatkan permintaan terhadap produk kecantikan meningkat. Peningkatan industri produk kecantikan didukung dengan banyaknya sumber daya yang dimiliki Indonesia. Selain itu, perkembangan industri produk kecantikan juga dipengaruhi dengan adanya 
perkembangan industri 4.0 saat ini. Perkembangan ini mengakibatkan banyak perubahan selera konsumen dan perubahan gaya hidup pada industri kecantikan yang ada di Indonesia. Seperti perilaku berbelanja yang menjadi sistem penjualan secara online. Dampak yang ditimbulkan yaitu banyak industri yang harus mengubah sistem penjualan dari toko konvensional menjadi perdagangan secara elektronik atau dikenal dengan E-commerce.

Hadirnya e-commerce mempermudah para pemasar maupun pembeli untuk bertransaksi. Salah satunya yaitu pada produk Max Factor, yang dimana produk Max Factor pada umumnya memiliki toko offline pada pusat perbelanjaan tertentu harus mengubah sistem penjualan menjadi $e$-commerce. Perubahan gaya hidup yang didukung dengan perkembangan teknologi, memungkinkan munculnya banyak marketplace di Indonesia. Salah satu marketplace yang mengkhususkan diri pada industri kecantikan yaitu PT Social Bella Indonesia atau Sociolla. Sociolla adalah perusahaan yang mengkhususkan diri pada industri produk kecantikan yang menjual produk kecantikan lokal maupun produk non-lokal melalui online store. (www.sociolla.com).

Namun berbelanja secara online belum tentu menjanjikan bahwa produk yang ada di website akan sama dengan barang yang diterima. Kurangnya informasi produk secara detail membuat konsumen sulit untuk memahami produk pada website. Sama halnya pada produk Max Factor yang ada di Sociolla, variasi produk yang disediakan terlalu sedikit dibandingkan dengan offline store maupun website asli Max Factor. Selain itu, ulasan produk terlalu sedikit pada website Sociolla sehingga membuat konsumen kurang percaya akan produk serta kurang menjamin keaslian produk dalam membeli secara online di website Sociolla. Maka niat pembelian konsumen terhadap produk Max Factor menjadi menurun.

Hal ini menuntut Sociolla untuk meningkatkan pemberian informasi mengenai produk yang lebih mendalam bagi para konsumennya agar para konsumen dapat teredukasi dan menambah wawasan. Selain itu, keterlibatan produk menjadi penting ketika konsumen memutuskan untuk membeli suatu produk. Karena semakin meningkatnya keterlibatan, konsumen memiliki motivasi yang lebih besar untuk memperhatikan, memahami, dan mencari tau informasi tentang produk yang mereka butuhkan.

Banyaknya penilaian dari konsumen melalui berbagai media sosial maupun dari mulut ke mulut baik secara positif maupun negatif sangat cepat mempengaruhi niat pembelian konsumen. E-WOM biasanya dianggap lebih dipercaya dibandingkan dari perusahaan dan dapat sangat mempengaruhi niat pembelian konsumen. Berdasarkan pengalaman konsumen yang sudah pernah berbelanja produk Max Factor di Sociolla terdapat penilaian bahwa kurangnya kualitas produk seperti kecepatan dalam pengiriman, kerusakan produk saat diterima, efek samping produk setelah penggunaan, daya tahan produk yang tidak sesuai dengan keterangan di website.

\section{KAJIAN TEORI}

Penelitian ini mengacu pada theory of planned behavior oleh Azjen (1991) yaitu teori yang menjelaskan niat individu untuk melakukan perilaku tertentu. Niat diasumsikan sebagai faktor kepercayaan individu dengan menggunakan informasi-informasi yang dimiliki yang pada akhirnya dapat memprediksi perilaku.

Menurut Keller (2013) niat pembelian merupakan bentuk dari perilaku konsumen yang berkeinginan untuk membeli atau memilih sebuah produk yang didasari oleh pengalaman, penggunaan dan keinginannya pada suatu produk.

Menurut Bucks (1985) pengetahuan produk terbagi menjadi tiga dimensi yaitu pengetahuan subyektif mengacu pada persepsi konsumen tentang yang dimiliki pengetahuan dan tekanan pada menilai pengetahuan produk dengan perasaan pribadi. Pengetahuan obyektif mengacu pada informasi, organisasi, dan bentuk disimpan dalam memori individu, 
yaitu kesadaran pribadi produk. Pengetahuan sebelumnya mengacu pada pengalaman masa lalu individu dalam pembelian atau menggunakan produk.

Menurut Peter \& Olson (2010) keterlibatan produk berkaitan dengan tingkat kepentingan pribadi yang dirasakan atau minat sehingga konsumen dapat bertindak dengan sengaja untuk meminimumkan resiko maupun memaksimumkan manfaat yang diperoleh dari pembelian dan pemakaian.

\section{Definisi Konseptual Variabel}

1. Pengetahuan Produk

Menurut Rachmawati, Suliyanto \& Suroso (2020) pengetahuan produk adalah " the level of experience and familiarity a person has with a product”. Elsya \& Indriyani (2020,) berpendapat pengetahuan produk adalah " the perception of knowledge possessed by consumers of a particular product, including the experience of consumers in using previous products. Selain itu Nurhayati \& Hendar (2019) menyatakan pengetahuan produk adalah, " a collection of various kinds of information that consumers have about the product, which includes product categories, brands, product terminology, product attributes or features, product prices and product trust". Berdasarkan beberapa definisi dapat disimpulkan pengetahuan produk adalah pengetahuan yang berdasarkan pada ingatan, pengetahuan, pemahaman dan persepsi konsumen sebelum menggunakan suatu produk tertentu yang meliputi kategori produk, merek, terminologi produk, atribut atau fitur produk, harga produk, dan kepercayaan produk.

2. Keterlibatan Produk

Menurut Bian \& Moutinho (2011) keterlibatan produk adalah persepsi konsumen tentang pentingnya kategori produk berdasarkan kebutuhan, nilai, dan minat yang melekat pada konsumen. Quester \& Lim (2003) memaparkan keterlibatan produk adalah " reflects the perceived relevance of the product category to the individual on an ongoing basis". Selain itu Gong (2020) berpendapat mengenai keterlibatan produk yaitu pemikiran dan perasaan konsumen terhadap suatu kategori produk. Berdasarkan beberapa definisi dapat disimpulkan bahwa keterlibatan produk adalah suatu pemahaman maupun persepsi konsumen tentang pentingnya mengkategorikan produk berdasarkan kebutuhan, nilai, dan minat pada suatu produk serta mencerminkan relevansi yang dirasakan dari kategori produk untuk individu secara berkelanjutan.

3. $E-W O M$

Menurut Fan, Y., \& Miao, Y. (2012) E-WOM adalah ulasan konsumen yang dapat digunakan oleh konsumen lain pada saat melakukan keputusan pembelian melalui perdagangan elektronik. Hennig-Thurau, Gwinner, Walsh and Gremler (2004) mendefinisikan bahwa E-WOM adalah, " any positive or negative statement made by potential, actual or former customers about a product or company which is made available to multiples of people and/or institutions and is spread over the internet". Selain itu menurut Jalilvand \& Samiei, (2012) komunikasi dari mulut ke mulut secara elektronik yaitu "ability to persuade customers and WOM as an antecedent and consequence of certain behaviours". Berdasarkan beberapa definisi dapat disimpulkan EWOM adalah komunikasi informal mengenai merek, produk maupun layanan baik secara positif atau negatif pada calon konsumen maupun konsumen tetap tentang suatu produk maupun perusahaan melalui internet.

4. Niat Pembelian 
Niat pembelian merupakan bentuk dari perilaku konsumen yang berkeinginan untuk membeli atau memilih sebuah produk yang didasari oleh pengalaman, penggunaan dan keinginannya pada suatu produk. Pengertian niat pembelian menurut Beneke, Sousa, Mbuyu \& Wickham (2016) niat pembelian adalah " the likelihood that an individual will purchase a particular product based on the interaction between customer needs, attitude and perception towards the product or brand". Khan, Ghauri \& Majeed (2012) berpendapat bahwa niat pembelian adalah "individual's intention to buy a specific brand individuals who want to buy a specific brand which they has chosen for themselves after certain evaluation". Selain itu Tuu \& Olsen (2011) menyatakan niat pembelian adalah “ the expectance and probability of buying a new product given a reference price in a timespecific frame". Berdasarkan beberapa definisi dapat disimpulkan niat pembelian adalah suatu keinginan seseorang untuk membeli produk tertentu berdasarkan interaksi antara kebutuhan, sikap dan persepsi pada suatu produk tertentu berdasarkan pilihan mereka sendiri yang telah melalui evaluasi serta sesuai dengan ekspektasi dan kemungkinan membeli produk baru dengan referensi harga pada waktu tertentu.

\section{Kaitan antar variabel}

1. Hubungan antara Pengetahuan Produk dengan Niat Pembelian

Menurut Shih, Sresteesang, Dao \& Wu (2018) tingkat pengetahuan konsumen terhadap suatu produk mempengaruhi penelusuran dan pemrosesan informasi. Menurut Yoshihiro, Kuo \& Shieh (2019) terdapat perbedaan konsumen yang memiliki pengetahuan produk yang lebih tinggi dan memiliki niat pembelian yang tinggi dibandingkan dengan pengetahuan produk yang rendah. Augusta, Mardhiyah, \& Widiastuti (2019) menyatakan bahwa pengetahuan produk tidak berpengaruh pada niat pembelian, karena para kaum milenial cenderung mengutamakan identitas sosial dan pengalaman serta mengikuti tren yang ada dan dianggap lebih terpercaya.

2. Hubungan antara Keterlibatan Produk dengan Niat Pembelian

Menurut Lee, Cheng, \& Shih (2017) produk dengan keterlibatan tinggi akan membuat konsumen lebih terlibat dalam menjangkau dan mencari informasi yang relevan tentang produk sehingga niat beli konsumen akan meningkat. Tariq, Nawaz, \& Butt (2013) berpendapat bahwa keterlibatan produk berpengaruh pada niat pembelian berdasarkan kesadaran dan loyalitas. Mayastuti, Suryani \& Wardana (2014) menyatakan bahwa citra merek yang kuat dan belum tentu dapat bersaing dengan merek yang lain. Sehingga keterlibatan akan produk menjadi rendah dan konsumen cenderung akan memilih merek lain yang lebih familiar bagi dirinya dan hal ini mengakibatkan niat beli konsumen menjadi menurun.

3. Hubungan antara E-WOM dengan Niat Pembelian

Menurut Jalilvand \& Samiei (2012) ketika E-WOM lebih efektif dibandingkan dengan promosi dari perusahaan dalam meningkatkan penjualan sehingga niat beli konsumen akan meningkat. Saleem \& Ellahi (2017) berpendapat bahwa E-WOM bergantung pada nilai, pengetahuan yang lebih banyak, kepercayaan, keterlibatan produk, informasi dan pengembangan platform media sosial yang dapat menarik sangat penting menarik niat beli konsumen. Menurut Ruhamak \& Rahayu (2016) semakin baik E-WOM, maka semakin baik respon konsumen terhadap niat pembelian. Hal ini sejalan dengan penelitian yang dilakukan oleh Yonita dan Budiono (2020) bahwa E-WOM terbukti dapat berpengaruh secara signifikan terhadap niat pembelian pada pengguna produk Innisfree di Jakarta. 
Berdasarkan kaitan-kaitan antar variabel di atas, maka model penelitian yang dirumuskan adalah sebagai berikut :

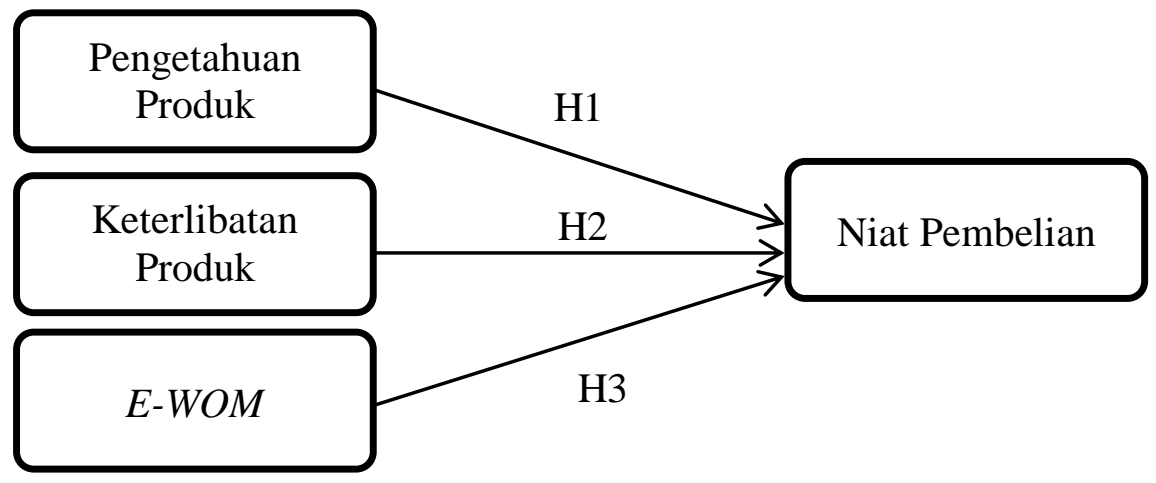

Gambar 1. Model Penelitian

H1 : Pengetahuan produk memiliki pengaruh positif signifikan terhadap niat pembelian produk Max Factor pada Mahasiswi Fakultas Ekonomi dan Bisnis Universitas Tarumanagara melalui website Sociolla di Jakarta.

H2 : Keterlibatan produk memiliki pengaruh positif signifikan terhadap niat pembelian produk Max Factor pada Mahasiswi Fakultas Ekonomi dan Bisnis Universitas Tarumanagara melalui website Sociolla di Jakarta.

H3 : E-WOM memiliki pengaruh positif signifikan terhadap niat pembelian produk Max Factor pada Mahasiswi Fakultas Ekonomi dan Bisnis Universitas Tarumanagara melalui website Sociolla di Jakarta.

\section{METODOLOGI}

Desain penelitian ini menggunakan desain penelitian deskriptif, karena penelitian dilakukan dengan tujuan mendeskripsikan sifat, karakteristik suatu gejala atau peristiwa. Penelitian ini mendeskripsikan niat pembelian mahasiswi Fakultas Ekonomi dan Bisnis Universitas Tarumanagara pada produk Max Factor melalui website Sociolla di Jakarta. Penelitian ini menggunakan cross-sectional design karena pengumpulan informasi hanya satu kali. Dalam penelitian ini metode yang akan digunakan adalah non probability sampling. Teknik pengambilan sampel pada penelitian ini adalaah purposive sampling. Pengambilan sampel dilakukan dengan menyebar kuesioner secara online kepada mahasiswi Fakultas Ekonomi dan Bisnis Universitas Tarumanagara yang mengetahui dan belum pernah membeli produk Max Factor pada website Sociolla di Jakarta. Jumlah sampel dalam penelitian ini adalah 100 sampel. Skala yang digunakan adalah skala likert dengan lima kategori respons yaitu 1 Sangat Tidak Setuju (STS), 2 Tidak Setuju (TS), 3 Netral (N), 4 Setuju (S), 5 Sangat Setuju (SS). Data diolah menggunakan software smartPLS 3 dengan teknik analisis data structural equation model (SEM). Terdapat 110 orang responden namun hanya 100 orang responden yang lolos dan sesuai dengan syarat yang ditentukan dalam penelitian ini. Teknik uji statistic dalam penelitian ini yaitu uji validitas dan uji reliabilitas dan teknik analisis data yang digunakan yaitu uji koefisien determinasi $\left(R^{2}\right)$, uji predictive relevance $\left(Q^{2}\right)$, uji effect size $\left(F^{2}\right)$, uji path coefficients, dan pengujian hipotesis. 


\section{HASIL ANALISIS DATA}

Berdasarkan hasil uji validitas, nilai uji loading factor menunjukkan bahwa pada setiap indikator lebih besar dari 0,7. Maka nilai uji loading factor memenuhi syarat validitas konvergen. Namun terdapat beberapa indikator yang harus dihapuskan karena tidak memenuhi syarat dan nilai loading factor lebih kecil dari 0,4 yaitu pada indikator PP5, KP5 dan EWOM3. Selain itu, berdasarkan hasil uji Average Variance Extracted (AVE) nilai pada setiap indikator lebih besar dari 0,5. Maka nilai uji AVE memenuhi syarat pada validitas konvergen. Berdasarkan nilai uji cross loading pada setiap indikator memiliki nilai yang lebih besar dibandingkan dengan nilai cross loading variabel yang lainnya dalam penelitian.

Berdasarkan hasil uji composite reliability menunjukkan bahwa nilai composite reliability pada setiap indikator lebih besar dari 0,7. Selain itu, nilai Cronbach's Alpha pada setiap indikator di atas 0,6 . Hal ini menunjukan bahwa variabel pada penelitian ini sudah realibel. Berdasarkan hasil uji koefisien determinasi $\left(R^{2}\right)$ diketahui nilai $R$ Square sebanyak $0,503(50,3 \%)$ variasi variabel niat pembelian dapat dijelaskan oleh variabel pengetahuan produk, keterlibatan produk dan E-WOM. Sisanya sebesar 49,7\% dapat dapat dijelaskan oleh variabel yang tidak diteliti dalam penelitian ini. Maka variabel dalam penelitian ini termasuk dalam tingkat yang sedang karena nilai $\mathrm{R}$ square di atas 0,5. Berdasarkan hasil uji Predictive Relevance, diketahui nilai $Q^{2}$ sebesar 0,330 dan nilai $\mathrm{Q}^{2}$ lebih besar dari $0(>0)$. Maka variabel dalam penelitian ini dapat dikatakan baik. Berdasarkan hasil uji effect size, diketahui bahwa variabel pengetahuan produk memiliki pengaruh yang kecil terhadap niat pembelian sebesar 0,061 . Variabel keterlibatan produk memiliki pengaruh yang sedang terhadap niat pembelian sebesar 0,114 . Variabel $E$-WOM memiliki pengaruh yang sedang terhadap niat pembelian sebesar 0,124 .

Tabel 2.

Hasil boothstrapping.

\begin{tabular}{|l|c|c|c|}
\hline \multicolumn{1}{|c|}{ Variabel } & $\begin{array}{c}\text { Path } \\
\text { Coefficients }\end{array}$ & t-statistic & $\boldsymbol{p}$-values \\
\hline $\begin{array}{l}\text { Pengetahuan Produk - } \\
>\text { Niat Pembelian }\end{array}$ & 0,216 & 2,020 & 0,044 \\
\hline $\begin{array}{l}\text { Keterlibatan Produk - } \\
>\text { Niat Pembelian }\end{array}$ & 0,301 & 2,228 & 0,026 \\
\hline $\begin{array}{l}E-W O M \text {-> Niat } \\
\text { Pembelian }\end{array}$ & 0,329 & 2,657 & 0,008 \\
\hline
\end{tabular}

\section{PEMBAHASAN}

Hasil pengujian hipotesis pertama menunjukkan variabel pengetahuan produk memiliki pengaruh positif terhadap niat pembelian produk Max Factor Pada Mahasiswi Fakultas Ekonomi \& Bisnis Universitas Tarumanagara Melalui Website Sociolla di Jakarta, sehingga dapat disimpulkan bahwa H1 tidak ditolak. Hal ini sejalan dengan hasil penelitian yang dilakukan oleh Shih, Sresteesang, Dao \& Wu (2018) dan Yoshihiro, Kuo \& Shieh (2019). Hasil penelitian tersebut yaitu pengetahuan produk memiliki pengaruh yang positif terhadap niat pembelian. Dalam penelitian tersebut dikatakan bahwa tingkat pengetahuan konsumen terhadap suatu produk mempengaruhi niat pembelian konsumen terhadap suatu produk.

Hasil pengujian hipotesis kedua menunjukkan variabel keterlibatan produk memiliki pengaruh positif terhadap niat pembelian produk Max Factor Pada Mahasiswi Fakultas Ekonomi \& Bisnis Universitas Tarumanagara Melalui Website Sociolla di Jakarta, sehingga dapat disimpulkan bahwa $\mathrm{H} 2$ tidak ditolak. Menurut penelitian lain yang dilakukan oleh 
Lee, Cheng, \& Shih (2017) dan Tariq, Nawaz, \& Butt (2013) mengatakan bahwa keterlibatan produk berpengaruh positif terhadap niat pembelian. Dalam penelitiannya keterlibatan tinggi akan membuat konsumen lebih mudah menjangkau dan mencari informasi lebih banyak terhadap produk sehingga niat beli konsumen meningkat.

Hasil pengujian hipotesis ketiga menunjukkan variabel E-WOM memiliki pengaruh positif terhadap niat pembelian produk Max Factor Pada Mahasiswi Fakultas Ekonomi \& Bisnis Universitas Tarumanagara Melalui Website Sociolla di Jakarta, sehingga dapat disimpulkan bahwa $\mathrm{H} 3$ tidak ditolak. Hal ini sejalan dengan hasil penelitian yang dilakukan Jalilvand \& Samiei (2012) dan Saleem \& Ellahi (2017) dimana E-WOM memiliki pengaruh yang positif terhadap niat pembelian. Dalam penelitiannya ia mengatakan dengan adanya $E$ WOM maka konsumen akan lebih percaya sehingga niat pembelian konsumen meningkat.

\section{PENUTUP}

1. Pengetahuan produk memiliki pengaruh positif signifikan terhadap niat pembelian produk Max Factor pada Mahasiswi Fakultas Ekonomi dan Bisnis Universitas Tarumanagara melalui website Sociolla di Jakarta.

2. Keterlibatan produk memiliki pengaruh positif signifikan terhadap niat pembelian produk Max Factor pada Mahasiswi Fakultas Ekonomi dan Bisnis Universitas Tarumanagara melalui website Sociolla di Jakarta.

3. E-WOM memiliki pengaruh positif signifikan terhadap niat pembelian pada produk Max Factor pada Mahasiswi Fakultas Ekonomi dan Bisnis Universitas Tarumanagara melalui website Sociolla di Jakarta.

Saran. Peneliti menyarankan agar perusahaan dapat mengambil keputusan di masa yang akan datang dengan memperhatikan kejelasan dalam meningkatkan informasi produk dan kejelasan produk Max Factor pada website Sociolla di Jakarta. Hal ini menjadi salah satu bagian yang penting dalam mencipkatan hubungan positif bagi para konsumen maupun calon konsumen yang akan membelin produk Max Factor. Selain itu, menciptakan keterlibatan produk yang tinggi bagi konsumen dengan memberikan kejelasan mengenai produk yang dijual merupakan produk yang memiliki kualitas yang baik sehingga konsumen dapat menilai bahwa produk Max Factor pada website Sociolla di Jakarta mempunyai kualitas dan konsumen dapat memberikan rekomendasi bagi calon konsumen lain sehingga akan meningkatkan niat pembelian.

\section{DAFTAR PUSTAKA}

Ajzen, I. (1991). The theory of planned behavior. Organizational behavior and human decision processes, 50(2), 179-211.

Augusta, E. D., Mardhiyah, D., \& Widiastuti, T. (2019). Effect of country of origin image, product knowledge, brand familiarity to purchase intention Korean cosmetics with information seeking as a mediator variable: Indonesian women's perspective. Dermatology Reports, 11(S1). https://doi.org/10.4081/dr.2019.8014

Beneke, J., de Sousa, S., Mbuyu, M., \& Wickham, B. (2016). The effect of negative online customer reviews on brand equity and purchase intention of consumer electronics in South Africa. International Review of Retail, Distribution and Consumer Research, 26(2), 171-201. https://doi.org/10.1080/09593969.2015.1068828

Bian, X., \& Moutinho, L. (2011). The role of brand image, product involvement, and knowledge in explaining consumer purchase behaviour of counterfeits: Direct and indirect effects. European Journal of Marketing, 45(1), 191-216. 
https://doi.org/10.1108/03090561111095658

Elsya, P., \& Indriyani, R. (2020). The Impact of Product Knowledge and Product Involvement to Repurchase Intention for Tupperware Products among Housewives in Surabaya, Indonesia. SHS Web of Conferences, 76, 01037.

https://doi.org/10.1051/shsconf/20207601037

Fan, Y.-W., \& Miao, Y.-F. (2012). Effect of Electronic Word-of-Mouth on Consumer Purchase Intention: the Perspective of Gender Differences. International Journal of Electronic Business Management, 10(3), 175-181.

Gong, W. (2020). Effects of parasocial interaction, brand credibility and product involvement on celebrity endorsement on microblog. Asia Pacific Journal of Marketing and Logistics. https://doi.org/10.1108/APJML-12-2019-0747

Goyette, I., Ricard, L., \& Bergeron, J. (2010). e-WOM Scale: Word-of-Mouth Measurement Scale for e-Services Context *. 23, 5-23. https://doi.org/10.1002/dir.10073

Hennig-Thurau, T., Gwinner, K. P., Walsh, G., \& Gremler, D. D. (2004). Electronic word-ofmouth via consumer-opinion platforms: What motivates consumers to articulate themselves on the Internet? Journal of Interactive Marketing, 18(1), 38-52.

https://doi.org/10.1002/dir.10073

Imran, K., \& Tauqir Ahmad, G. (2012). Impact of Brand Related Attributes on Purchase Intention of Customers. Interdisciplinary Journal of Contemporary Research in Business, 4(3), 194-200.

Jalilvand, M. R., \& Samiei, N. (2012). The effect of electronic word of mouth on brand image and purchase intention: An empirical study in the automobile industry in Iran. Marketing Intelligence and Planning, 30(4), 460-476. https://doi.org/10.1108/02634501211231946

Lee, W. I., Cheng, S. Y., \& Shih, Y. T. (2017). Effects among product attributes, involvement, word-of-mouth, and purchase intention in online shopping. Asia Pacific Management Review, 22(4), 223-229. https://doi.org/10.1016/j.apmrv.2017.07.007

Mayastuti, I. G. A. P. U., Suryani, A. A., \& Wardana, I. M. (2014). Peran product involvement dalam memoderasi pengaruh country of origin terhadap purchase intention smartphone merek oppo di kota denpasar. E-Jurnal Manajemen Universitas Udayana, 3(12). https://ocs.unud.ac.id/index.php/Manajemen/article/view/9990

Nurhayati, T., \& Hendar, H. (2019). Personal intrinsic religiosity and product knowledge on halal product purchase intention: Role of halal product awareness. Journal of Islamic Marketing, 11(3), 603-620. https://doi.org/10.1108/JIMA-11-2018-0220

Quester, P., \& Lin Lim, A. (2003). Product involvement/brand loyalty: Is there a link? Journal of Product \& Brand Management, 12(1), 22-38.

https://doi.org/10.1108/10610420310463117

Rachmawati, E., Suliyanto, S., \& Suroso, A. (2020). A moderating role of halal brand awareness to purchase decision making. Journal of Islamic Marketing.

https://doi.org/10.1108/JIMA-05-2020-0145

Ruhamak, M. D., \& Rahayu, B. (2017). Pengaruh Word Of Mouth Terhadap Purchase Intention Melalui Brand Image Pada Lembaga Kursus Bahasa Inggris Dynamic English Course Pare. Ekonika: Jurnal Ekonomi Universitas Kadiri, 1(2), 188-204.

https://doi.org/10.30737/ekonika.v1i2.14

Saleem, A., \& Ellahi, A. (2019). Influence of Electronic Word of Mouth on Purchase Intention of Fashion Products on Social Networking Websites. International Journal of Scientific and Technology Research, 8(10), 1-5.

Shih, K.-H., Stresteesang, W., Dao, N. T. B., \& Wu, G.-L. (2018). Assesing the relationship among online word of mouth, product knowledge and purchase intention in chain restaurant. Journal of Accounting, Finance \& Management Strategy, 13(1), 57-76. 
Tariq, M. I., Rafay Nawaz, M., Nawaz, M. M., \& Butt, H. A. (2013). Customer Perceptions about Branding and Purchase Intention: A Study of FMCG in an Emerging Market. $J$. Basic. Appl. Sci. Res, 3(2), 340-347.

Yonita, T., \& Budiono, H. (2020). Pengaruh Ewom Terhadap Brand Image dan Purchase Intention Produk Innisfree di Jakarta. Jurnal Manajerial dan Kewirausahaan, 2(1), 152-161. https://journal.untar.ac.id/index.php/JMDK/issue/view/324

Yoshihiro, Y., Kuo, H. M., \& Shieh, C. J. (2019). The impact of seniors' health food product knowledge on the perceived value and purchase intention. Revista de Cercetare Si Interventie Sociala, 64, 199-212. https://doi.org/10.33788/rcis.64.16 